\title{
Faktor-faktor yang Mempengaruhi Minat Berwirausaha Mahasiswa Pendidikan Ekonomi STKIP PGRI Lumajang Tahun Akademik 2020/2021
}

\author{
Muhammad Zunaedy \\ e-mail: mzunaedy@gmail.com \\ Siti Aisyah \\ e-mail: iisamunaris@gmail.com \\ Triwilujeng Ayuningtyas \\ e-mail: triwilujengayuningtyas5@gmail.com \\ (Program Studi Pendidikan Ekonomi, Fakultas Ekonomi, STKIP PGRI Lumajang)
}

\begin{abstract}
ABSTRAK : Tujuan Penelitian untuk mengetahui analisis minat berwirausaha pendidikan ekonomi angkatan 2016 penelitian ini mengangkat permasalahan: Faktor-Faktor apa saja yang mempengaruhi minat berwirausaha mahasiswa pendidikan ekonomi angkatan 2016 di STKIP PGRI Lumajang? Jenis penelitian yaitu penelitian kualitatif dengan pendekatan fenomenologi. Subjek penelitian yaitu mahasiswa pendidikan ekonomi di STKIP PGRI Lumajang dengan jumlah informan sebanyak 9 mahasiswa. teknik pengumpulan data yang digunakan yaitu dengan observasi dan wawancara kepada informan. Dengan teknik analisis data berupa pengumpulan data, reduksi data dan penarikan kesimpulan atau verifikasi. hasil penelitian dan pembahasan rata-rata minat sesuai dengan hasil observasi sekitar $93.86 \%$ setuju dengan pilihannya, dan berwirausaha sesuai dengan hasil observasi sekitar 95.97\% setuju dengan pilihannya, Minat berwirausaha sesuai dengan hasil observasi sekitar $63.6 \%$ setuju dengan pilihannya, Kesimpulan dari penelitian ini bahwa minat berwirausaha dari mahasiswa angkatan 2016 cukup besar dan semakin tinggi minat berwirausaha mahasiswa maka semakin tinggi pula minat untuk menjadi wirausahawan.
\end{abstract}

\section{Kata kunci - Faktor-Faktor, Minat Berwirausaha, Mahasiswa}

\begin{abstract}
The research objective was to determine the analysis of the interest in entrepreneurship in economic education class 2016. This research raised the problem: What factors influence the entrepreneurial interest of students of economic education class 2016 at STKIP PGRI Lumajang ? This type of research is qualitative research with a phenomenological approach. The research subjects were students of economic education at STKIP PGRI Lumajang with 9 students as informants. Data collection techniques used are observation and interviews with informants. With data analysis techniques in the form of data collection, data reduction and drawing conclusions or verification. The results of research and discussion of the average interest in accordance with the results of observations are about $93.86 \%$ agree with the choice, and entrepreneurship according to the observation results about $95.97 \%$ agree with the choice, Interests in entrepreneurship are in accordance with the results of observations about $63.6 \%$ agree with the choice, the conclusion of this study is that The interest in entrepreneurship from students of class 2016 is quite large and the higher the interest in entrepreneurship among students, the higher the interest in becoming entrepreneurs.
\end{abstract}

Kata kunci - Factors, Entrepreneurial Interest, Students 


\section{PENDAHULUAN}

Fenomena di atas seharusnya dapat dijadikan bahan pemikiran, bagaimana agar dapat menciptakan lapangan kerja baru yang dapat menampung karyawan, tidak lagi berpikir untuk mempersiapkan diri menjadi calon karyawan yang mencari pekerjaan, terutama bagi individu yang terdidik, misalnya mahasiswa. Mereka diharapkan mampu menjadi penggerak perekonomian dengan menanamkan jiwa kewirausahaan semenjak dini.

Menurut Rahardja (2012) minat berwirausaha adalah kecenderungan dalam diri seseorang untuk tertarik dalam menciptakan suatu usaha yang kemudian mengorganisir, mengatur, menanggung resiko dan mengembangkan usaha yang diciptakannya sendiri.danMinat berwirausaha adalah pemusatan perhatian, keinginan, ketertarikan, serta kesediaan individu pada bidang wirausaha untuk bekerja keras atau berkemauan keras untuk berusaha memenuhi kebutuhan hidupnya tanpa merasa takut dengan resiko yang akan terjadi, serta berkemauan keras untuk belajar dari kegagalan (Wulandari, 2013).jadi dapat disimpulkan bahwa minat berwirausaha adalah ketertarikan seseorang atau individu dalam berwirausaha untuk bekerja keras yang kemudian mengatur dan mengembangkan usahanya tanpa rasa takut mengganggu risiko yang terjadi dan belajar dari kegagalan.

Terdapat berbagai faktor yang mempengaruhi minat berwirausaha pada mahasiswa (Lestari dan Wjiaya, 2012; Nastiti dkk, 2010; Suharti dan Sirine, 2012; Suhartini, 2011), diantaranya adalah: 1) Ekspektasi pendapatan. Seseorang akan tertarik untuk menjadi wirausaha karena ekspektasi pendapatan yang diperolehnya jika sukses melebihi karyawan.Seseorang dengan ekspektasi pendapatan yang lebih tinggi daripada bekerja menjadi karyawan menjadi daya tarik untuk menjadi wirausaha; 2) Lingkungan keluarga dan masyarakat.Semakin kondusif lingkungan keluarga dan masyarakat disekitarnya maka akan semakin mendorong seseorang untuk menjadi seorang wirausaha. Apabila lingkungan keluarga dan masyarakat mendukung maka seseorang akan semakin tinggi niatnya untuk menjadi wirausaha dibandingkan jika tidak memiliki dukungan dari lingkungan keluarga dan masyarakat; 3) Pendidikan. Apabila pendidikan memadai maka seseorang akan siap untuk menjadi seorang wirausaha dan memimpin anak buahnya.

Latar belakang Pendidikan merupakan perkara penting dalam membangun sebuah negeri, rusaknya pendidikan akan melahirkan generasi yang rusak pula untuk mempersiapkan SDM sebelum memasuki pasar kerja. Dengan pengetahuan yang diperolehnya dari pendidikan yang diharapkan sesuai dengan syarat-syarat yang dituntut oleh suatu pekerjaan, Sari Kemals dan Dini Sri (2013). Di STKIP PGRI Lumajang sendiri, terdapat mata kuliah kewirausahaan yang sangat berperan dalam memberikan pembelajaran dan juga dapat memberikan dorongan atau minat agar nantinya output atau lulusan yang dihasilkan tidak hanya berperan dalam dunia pendidikan tapi juga memberikan kontribusi di dalam dunia kewirausahaan, seperti menciptakan bisnis atau menciptakan usaha sendiri. Dengan memanfaatkan dan membangun peluang bisnis yang ada, yang didapat bukan hanya penghasilan untuk diri sendiri, tapi juga dapat memberikan lowongan pekerjaan untuk masyarakat sekitar. Karena berwirausaha bukan untuk membangun, memiliki, dan menjalankan untuk dirinya sendiri tapi juga orang lain. Apalagi dengan majunya teknologi informasi dan komunikasi, dunia wirausaha juga akan semakin bersaing untuk bisa menjadi yang lebih unggul. Sehingga, mata kuliah pendidikan kewirausahaan sangat penting dan sangat dibutuhkan untuk meningkatkan minat kewirausahaan mahasiswa STKIP PGRI Lumajang.

Minat berwirausaha merupakan salah satu pendorong untuk memulai usaha guna mencapai taraf hidup yang lebih baik, salah satunya mengatasi pengangguran dan kemiskinan yang terjadi saat ini. Dalam penelitian ini, minat berwirausaha mahasiswa STKIP PGRI Lumajang berpengaruh positif dan signifikan terhadap pendidikan ekonomi angkatan 2016 di STKIP PGRI Lumajang. Pendidikan ekonomi mahasiswa harus didukung dengan adanya minat berwirausaha agar dapat memberikan dorongan pada mahasiswa dan diharapkan nantinya menghasilkan lulusan yang tidak hanya 
berperan dalam dunia pendidikan tapi juga memberikan kontribusi di dalam dunia kewirausahaan. Meskipun sebelumnya mahasiswa telah dibekali mata kuliah kewirausahaan tetapi minat mahasiswa terhadap berwirausaha masih kurang. Hal ini perlu diatasi, dengan memberikan pengetahuan kembali kepada mahasiswa mengenai minat berwirausaha.

\section{TINJAUAN PUSTAKA}

A. Minat

Minat merupakan suatu rasa lebih suka dan rasa keterikatan pada suatu hal atau aktivitas, tanpa ada yang menyuruh. Minat pada dasarnya adalah penerimaan akan suatu hubungan antara diri sendiri dengan sesuatu diluar diri. (Slameto, 2010: 180). Minat dapat diekspresikan melalui pernyataan yang menunjukkan bahwa siswa lebih menyukai suatu hal dibandingkan hal lainnya, dapat pula dimanifestasikan melalui partisipasi dalam suatu aktivitas. Syah (2011: 152), mengemukakan bahwa "minat (interest) berarti kecenderungan dan kegairahan yang tinggi atau keinginan yang besar terhadap sesuatu". Ketertarikan ditunjukkan melalui partisipasi yang nantinya akan membuat seseorang ingin melakukan hal ia sukai dan akan berusaha mempelajari lebih dalam lagi tentang hal yang ia sukai.

Dari beberapa pendapat tersebut dapat disimpulkan bahwa minat merupakan kesadaran seseorang yang menimbulkan adanya keinginan suatu hal dibandingkan hal lainnya dengan berpartisipasi aktif melakukan kegiatan yang menjadi objek kesukaannya tanpa adanya paksaan. Keinginan dalam diri individu tersebut dinyatakan dalam suka atau tidak suka terhadap suatu keinginan yang akan memuaskan kebutuhan. Minat dapat dikembangkan dan ditumbuhkan karena pengaruh lingkungan sekitarnya.Munculnya minat ini biasanya ditandai dengan adanya dorongan atau motif, perhatian rasa senang, kemampuan dan kecocokan atau kesesuaian.

Dimensi dan Indikator Minat, Minat sebenarnya mengandung tiga unsur yaitu unsur kognisi (mengenal), emosi (perasaan), dan konasi (kehendak). Hidayat (2013:89) membagi ketiga unsur tersebut menjadi beberapa indikator yang menentukan minat seseorang terhadap sesuatu, antara lain:

a. Keinginan

Seseorang yang memiliki keinginan terhadap suatu kegiatan tentunya ia akan melakukan atas keinginan dirinya sendiri.Keinginan merupakan indikator minat yang datang dari dorongan diri, apabila yang dituju sesuatu yang nyata.Sehingga dari dorongan tersebut timbul keinginan dan minat untuk mengerjakan suatu pekerjaan.

b. Perasaan Senang

Seseorang yang memiliki perasaan senang atau suka dalam hal tertentu ia cenderung mengetahui hubungan antara perasaan dengan minat

c. Perhatian

Adanya perhatian merupakan konsentrasi atau aktivitas jiwa seseorang terhadap pengamatan, pengertian, dan sebagainya dengan mengesampingkan yang lain.

d. Perasaan Tertarik 
Minat bisa berhubungan dengan gaya gerak yang mendorong kita cenderung atau rasa tertarik pada orang, benda, atau kegiatan ataupun bisa berupa pengalaman yang efektif yang dirangsang oleh kegiatan itu sendiri. Orang yang memiliki minat yang tinggi terhadap sesuatu akan terdapat kecenderungan yang kuat tertarikpada guru dan mata pelajaran yang diajarkan. Sehingga perasaan tertarik merupakan indikator yang menunjukkan minat seseorang.

e. Giat Belajar

Aktivitas di luar sekolah merupakan indikator yang dapat menunjukkan keberadaan minat pada diri siswa.

f. Mengerjakan Tugas

Kebiasaan mengerjakan tugas yang diberikan guru merupakan salah satu indikator yang menunjukkan minat siswa.

g. Menaati Peraturan

Orang yang berminat terhadap pelajaran dalam dirinya akanterdapat kecenderungankecenderungan yang kuat untuk mematuhidan menaati peraturan-peraturan yang ditetapkan karena ia mengetahui konsekuensinya. Sehingga menaati peraturan merupakan indikator yang menentukan minat seseorang.

B. Berwirausaha

Menurut Novitasyari (2017) mengemukakan Kewirausahaan berasal dari kata wira dan usaha, dan diberi imbuhan ke-an. Wira dapat diartikan sebagai pahlawan, pejuang atau gagah berani, sedangkan usaha adalah bekerja atau melakukan sesuatu.Kewirausahaan (entrepreneurship) adalah perilaku dinamis yang berani mengambil resiko serta kreatif dan berkembang.

Vernia Mila Dellia (2018) entrepreneur (wirausaha) adalah orang yangmendirikan, menjalankan danmelembagakan usaha yang dimilikinya. Menurut Setiawati (2017) Entrepeneur atau wirausaha adalah seseorang yang mampu menciptakan sesuatu yang baru baik barang ataupun jasa dalam suatu organisasi dan mampu mendobrak sistem ekonomi yang ada. Wirausaha (entrepreneur) adalah seseorang yang tangguh melakukan sesuatu. Sedangkan Rahmawati (2017) Berwirausaha adalah salah satu cara untuk membangun, memiliki, dan menjalankan usaha (bisnis) agar dapatbermanfaat bagi diri sendiri dan orang lain.

Jadi, berdasarkan pengertian beberapa para ahli, dapat disimpulkan bahwa berwirausaha merupakan suatu cara yang dilakukan seseorang dalam membangun atau menciptakan sesuatu yang baru (inovatif) baik barang maupun jasa dimana orang tersebut merupakan pelaku utama dalam pembangunan ekonomi yang memiliki perilaku dinamis yang berani mengambil resiko, kreatif, dan berkembang.

Banyak orang yang ingin berwirausaha, namun mereka terkadang berhenti ditengah jalan atau bahkan mundur sebelum memulainya. Mereka tidak tahu bagaimana caranya, atau takut mengalami kegagalan. Menurut Hendro (2011), sisi kekuatan karakter emosilah yang membedakan seorangwirausaha dengan orang biasa, kerakter tesebut ialah:

a. Pandai mengelola ketakutan 
Orang yang pandai mengelola ketakunya ini akan mengubah ketakutan menjadi sesuatu yang hati-hati dalam bertindak dan membangkitkan keberanian dan percaya diri dalam menghadapi resiko.

b. Mempunyai iris mata yang berbeda dengan orang lain

Iris mata adalah cara seseorang memandang sesuatu masalah,kesulitan, perubahan, diri sendiri, lingkungan, tren dan kejadian untuk memunculkan ide-ide, gagasan dan konsep yang diinginkan demi memajukan usahanya.

c. Mempunyai keteguhan hati yang tinggi

Keteguhan hati membuat seseorang berbeda didalam memandang suatu kegagalan, orangorang yang memiliki keteguhan hati kegagalan itu tidak ada, yang ada hanyalah suatu rintangan besar, sangat besar dan kecil.

d. Tidak merima apa yang ada didepannya dan selalu mencari yang terbaik

Seseorang yang berkarakter wirausaha harus mampu memberikan yang terbaik untuk pelanggannya, anggapannya adalah jika memberikan sesuatu yang buruk kepada pelanggan maka akan berdampak buruk pada dirinya sendiri, dan berakibat fatal pada usahanya.

Indikator Berwirausaha menurut Engle et al. (2010) diantaranya: 1) Senang berwirausaha, 2) Kesiapan untuk berwirausaha, 3) Pertimbangan yang matang untuk berwirausaha, 4) Memutuskan untuk berwirausaha,

C. Minat Berwirausaha

Menurut Wulandari (2013) minat wirausaha adalah gejala psikis untuk memusatkan perhatian dan berbuat sesuatu terhadap wirausaha itu dengan perasaan senang karena membawa manfaat bagi dirinya. Minat menjadiwirausaha didefinisikan sebagai keinginan seseoran guntuk bekerja mandiri (selfemployed) ataumenjalankan usahanya sendiri. Menurut pendapat Budiati (2012) menyatakan bahwa minat mahasiswa menjadi wirausaha dibagi dalam empat kelompok yaitu:

1) Minat untuk memulai wirausaha dalam jangka waktu dekat,

2) Minat untuk memulai wirausaha dua tahun mendatang,

3) Minat untuk memulai wirausaha untuk jangka panjang, dan

4) Tidak memiliki minat berwirausaha

Banyak faktor psikologis yang membentuk sikap negatif masyarakat sehingga kurang berminat terhadap profesi wirausaha, antara lain sifat agresif, bersaing, egois, tidak jujur, sumber penghasilan tidak stabil, kurang terhormat. Landasan fisiologi seorang tua tidak menginginkan anak-anaknya untuk terlibat dalam bidang bisnis, menyebabkan masyarakat Indonesia tidak termotivasi di dunia bisnis. Namun saat ini, pendapat tersebut berubah, anak muda mulai tertarik dengan profesi bisnis yang cukup menjanjikan masa depan yang cerah. Hal ini didorong oleh kondisi persaingan dunia kerja yang ketat sehingga dituntut untuk mampu menciptakan peluang kerja baru.

Jadi, berdasarkan pendapat para ahli tersebut terkait minat berwirausaha dapat dinyatakan bahwa seseorang yang memiliki minat berwirausaha berarti memiliki rasa percaya diri, dapat mengambil resiko, kreatif dan inovatif,disiplin dan kerja keras, berorientasi ke masa depan,memiliki rasa ingin tahu, jujur 
dan mandiri.

\section{METODE}

Jenis penelitian ini adalah penelitian kualitatif dengan pendekatan fenomenologi. Pendekatan fenomenologi digunakan sesuai dengan fenomena digunakan untuk mengetahui secara langsung tentang Analisis Minat berwirausaha Mahasiswa Pendidikan Ekonomi angkatan 2016 STKIP PGRI Lumajang Tahun Akademik 2020/2021. Lokasi penelitian dilaksakan di STKIP PGRI Lumajang, informan dalam penelitian ini yaitu mahasiswa pendidikan ekonomi angkatan 2016 yang berjumlah 9 informan.

Pemilihan subjek penelitian menggunakan metode purposive sampling dimana mahasiswa di anggap menjadi informan yang tepat dan diharapkan mengetahui tentang apa yang akan di teliti. Sumber data dalam penelitian yaitu berupa sumber data primer dan data sekunder. Prosedur pengumpulan data dalam penelitian ini terdiri dari tiga prosedur, yaitu: (1) observasi, (2) wawancara, dan (3) dokumentasi. Dalam analisis data menggunakan pengumpulan data, reduksi data, dan penarikan kesimpulan atau verifikasi, serta untuk pengujian keabsahan data menggunakan uji Credibility, uji transferability, uji dependability, dan uji Confirmability.

\section{PEMBAHASAN}

Penelitian ini bertujuan untuk mengetahui faktor-faktor yang mempengaruhi minat berwirausaha mahasiswa pendidikan ekonomi angkatan 2016 di STKIP PGRI Lumajang. Dalam penelitian ini, penulis menggunakan kuisioner untuk mengetahui hasil penelitian dengan adanya data tambahan berupa angket yang diisi informan. Hasil kuisioner data yang diperoleh tentang minat berwirausaha mahasiswa pendidikan ekonomi angkatan 2016 di STKIP PGRI Lumajang dapat dilihat pada tabel 1.

Tabel 1. Hasil observasi ( data kuisioner)

\begin{tabular}{llcc}
\hline No & \multicolumn{1}{c}{ Pernyataan } & Ya & Tidak \\
\hline 1 & Apakah anda memiliki keinginan minat berwirausaha? & 100 & 0 \\
\hline 2 & $\begin{array}{l}\text { Apakah perasaan senang atau tidaknya berpengaruh dengan } \\
\text { minat berwirausaha? }\end{array}$ & 100 & 0 \\
\hline 3 & $\begin{array}{l}\text { Apakah dengan adanya perasaan senang dapat } \\
\text { meningkatkan minat Berwirausaha? }\end{array}$ & 100 & 0 \\
\hline 4 & $\begin{array}{l}\text { Apakah rasa perhatian perlu ada untuk memunculkan rasa } \\
\text { minat Berwirausaha? }\end{array}$ & 90.6 & 9.4 \\
\hline 5 & $\begin{array}{l}\text { Apakah uang saku Anda cukup untuk memenuhi kebutuhan } \\
\text { kuliah? }\end{array}$ & 93.8 & 6.3 \\
\hline 6 & $\begin{array}{l}\text { Apakah giat belajar merupakan suatu hal yang dapat } \\
\text { menimbulkan minat dalam berwirausaha? }\end{array}$ & 78.8 & 21.2 \\
\hline \multicolumn{4}{c}{ Rata-Rata Minat } \\
\hline 7 & Apakah anda senang dengan berwirausaha? & 100 & 0 \\
\hline 8 & $\begin{array}{l}\text { Apakah dalam berwirausaha perlu adanya pertimbangan } \\
\text { yang matang? }\end{array}$ & 97 & $\mathbf{6 . 1 4 \%}$ \\
\hline 9 & $\begin{array}{l}\text { Apakah berwirausaha merupakan keputusan yang baik bagi } \\
\text { mahasiswa? }\end{array}$ & 90.9 & 9.1 \\
\hline \multicolumn{1}{c}{ Rata-rata Berwirausaha } & $\mathbf{9 5 . 9 7 \%}$ & $\mathbf{4 . 0 3 \%}$ \\
\hline 10 & $\begin{array}{l}\text { Apakah tidak ada ketergantungan pada orang lain } \\
\text { merupakan salah satu hal penting pada minat berwirausaha? }\end{array}$ & 63.6 & 36.4 \\
\hline
\end{tabular}




\begin{tabular}{lllc}
\hline 11 & $\begin{array}{l}\text { Apakah dapat membantu lingkungan sosial merupakan } \\
\text { salah satu hasil yang dapat dicapai dalam berwirausaha? }\end{array}$ & 87.9 & 12.1 \\
\hline 12 & $\begin{array}{l}\text { Apakah rasa senang jadi wirausahawan merupakan salah } \\
\text { satu motivasi dari minat berwirausaha? }\end{array}$ & 100 & 0 \\
\hline
\end{tabular}

Berdasarkan tabel 1 terlihat bahwa rata-rata minat sebesar 93.86\%, sedangkan untuk yang menjawab tidak sebesar $6.14 \%$. Menurut Yonaevy (2015) menyatakan perhatian atau ketertarikan merupakan salah satu aspek yang berperan penting dalam mempengaruhi minat, aspek perhatian merupakan sesuatu yang menarik individu untuk berinovasi, berkreatif, dan memperoleh peluang usaha. Apabila seorang individu tertarik dengan suatu kegiatan yaitu kegiatan berwirausaha maka yang bersangkutan akan melakukan kegiatan tersebut. Individu memiliki keinginan yang tinggi untuk berusaha secara mandiri dan berani menghadapi resiko dan adanya keyakinan pada diri sendiri. Keyakinan subjek juga tinggi apabila kegiatan yang dilakukan memperoleh penghargaan dan dukungan orang lain maka akan mendorong individu untuk melakukan kegiatan dengan senang hati dan ditunjang dengan melakukan aktivitas-aktivitas yang menunjang kegiatan wirausaha yang dijalankan subjek

Hasil kuesioner data dari variabel berwirausaha menyatakan bahwa $95.97 \%$ yang menjawab dengan pilihan ya, sedangkan yang memilih pilihan tidak sebesar $4.03 \%$. Hal ini sesuai dengan pendapat Rahmawati (2017), menyatakan setelah menempuh mata kuliah kewirausahaan, mahasiswa diharapkan dapat menerapkan ilmu-ilmu yang didapat dari kegiatan seminar kewirausahaan. Mahasiswa diharapkan mengikuti setiap kegiatan kewirausahaan agar wawasan tentang berwirausaha semakin luas. Dengan belajar mata kuliah kewirausahaan dapat menumbuhkan insiatif bagi mahasiswa agar menciptakan usaha sendiri.

Pada penelitian ini, minat berwirausaha dengan hasil observasi rata-rata minat berwirausaha sebesar $63,6 \%$ memilih pilihan ya dalam pengisian kuisioner dan wawancara terhadap beberapa responden mengenai minat berwirausaha. Indikator dalam minat berwirausaha terdiri atas tidak ada ketergantungan pada orang lain, dapat membantu lingkungan sosial, senang jika menjadi seorang wirausahawan, ketersediaan untuk bekerja keras dan tekun untuk mencapai kemajuan usaha, ketersediaan menanggung berbagai macam resiko, bersedia menempuh jalur dan cara baru, dan ketersediaan untuk hidup hemat. Seluruh indikator tersebut sebagai acuan dalam minat berwirausaha maka dapat disimpulkan bahwa minat berwirausaha sebesar 63,6\% sedangkan yang kurang minat sebesar $36,4 \%$, hal ini membuktikan bahwa minat berwirausaha dari mahasiswa angkatan 2016 cukup besar. Hal ini sesuai dengan pendapat Budiati (2012), bahwa semakin tinggi minat berwirausaha mahasiswa maka semakin tinggi pula minat untuk menjadi wirausahawan.

Sedangkan hasil wawancara untuk mengetahui minat berwirausaha mahasiswa dengan menggunakan variabel berupa minat berwirausaha ekonomi mahasiswa. Penjabaran dalam analisis ini memungkinkan peneliti untuk menarik lebih spesifik dalam mengetahui minat berwirausaha mahasiswa pendidikan ekonomi angkatan 2016 di STKIP PGRI Lumajang Tahun Akademik 2020/2021.

Terdapat beberapa faktor yang mempengaruhi minat berwirausaha mahasiswa pendidikan ekonomi angkatan 2016 di STKIP PGRI Lumajang, antara lain:

a. Keinganan

Seseorang yang memiliki keinginan terhadap suatu kegiatan tentunya ia akan melakukan atas keinginan dirinya sendiri. Keinginan merupakan indikator minat yang datang dari dorongan diri, apabila yang dituju sesuatu yang nyata. Sehingga dari dorongan tersebut timbul keinginan dan minat untuk mengerjakan suatu pekerjaan. Dari yang diungkapkan oleh mahasiswa pendidikan ekonomi angkatan 2016 di STKIP PGRI Lumajang. mereka sama-sama berpendapat bahwa keinginan untuk berwirausaha muncul dari diri sendiri tanpa ada dorongan orang lain. Hal ini sesuai dengan 
pernyataan Misrah (2019) "keinginan dapat muncul pada diri seseorang karena adanya indikator tertentu salah satunya yaitu minat yang dapat dijadikan dorongan pada dirinya sendiri, hal tersebut dapat memicu seseorang untuk melakukan tindakan agar dapat mencapai keinginannya.

b. Perasaan Senang

Seseorang yang memiliki rasa senang atau suka dalam hal tertentu, ia cenderung mengetahui hubungan antara perasaan dengan minatnya sehingga dengan adanya rasa tersebut dalam melakukan suatu hal akan terasa jauh lebih ringan daripada biasanya.. Dari yang diungkapkan oleh mahasiswa pendidikan ekonomi angkatan 2016 di STKIP PGRI Lumajang., sama-sama berpendapat bahwa perasaan senang berpengaruh dalam berwirausaha itu sendiri. Menurut Purnamasari (2018) "Rasa senang terhadap hal-hal tertentu dapat mempengaruhi tindakan seseorang terutama dalam pekerjaan, dalam dunia pekerjaan ketika seseorang memiliki rasa senang atau suka dengan apa yang dilakukannya maka pekerjaan yang dilakukannya terasa lebih ringan daripada biasanya.

c. Perhatian

Adanya perhatian adalah adanya rasa perhatian yang konsentrasi atau aktivitas jiwa seseorang terhadap pengamatan, pengertian, dan sebagainya dengan mengesampingkan yang lain. Dari yang diungkapkan oleh mahasiswa pendidikan ekonomi angkatan 2016 di STKIP PGRI Lumajang., kita dapat menyimpulkan bahwa rasa perhatian merupakan aspek penting yang berpengaruh terhadap minat berwirausaha. Menurut Yonaevy (2016) " Perhatian merupakan salah satu cara untuk memunculkan rasa minat terhadap suatu hal salah satunya dalam dunia bisnis. Dengan adanya rasa perhatian akan sesuatu maka dapat memicu rasa ketertarikannya terhadap hal yang ingin dilakukannya.

d. Perasaan Tertarik

Perasaan tertarik adalah minat bisa berhubungan dengan gaya gerak yang mendorong kita cenderung atau rasa tertarik pada orang, benda, atau kegiatan ataupun bisa berupa pengalaman yang efektif yang dirangsang oleh kegiatan itu sendiri. Dari yang diungkapkan oleh mahasiswa pendidikan ekonomi angkatan 2016 di STKIP PGRI Lumajang, maka dapat dikategorikan untuk perasaan tertarik sangat berpengaruh. Hal ini sesuai dengan pernyataan Slameto (2010) "Perasaan tertarik merupakan salah satu indikator untuk menunjukkan minat pada suatu hal. Hal ini-lah yang mengakibatkan bahwa perasaan tertarik tidak bisa dipisahkan sebab sebelum terjun di dunia bisnis pasti perlu adanya ketertarikan di dunia tersebut.

e. Giat Belajar

Aktivitas di luar sekolah merupakan indikator yang dapat menunjukkan keberadaan minat pada diri siswa. Dari yang diungkapkan oleh mahasiswa pendidikan ekonomi angkatan 2016 di STKIP PGRI Lumajang dapat disimpulkan bahwa giat belajar merupakan proses yang sangat penting untuk mewujudkan suatu minat berwirausaha itu sendiri dan dalam proses belajar tersebut dapat kita peroleh dari berbagai media misalnya buku televisi online dan sebagainya. Menurut Susanto (2014) "Giat belajar merupakan salah satu indeks yang menggambarkan bahwa orang tersebut memiliki minat terhadap apa yang akan dicapainya, giat belajar dapat muncul akibat rasa ingin tahu akan apa yang akan dikerjakannya sebab dengan munculnya giat belajar pada diri seseorang, maka orang tersebut berusaha mencari suatu hal dalam proses belajar tersebut untuk mencapai keinginannya khususnya di dunia wirausaha.

f. Mengerjakan Tugas

Kebiasaan mengerjakan tugas yang diberikan guru merupakan salah satu indikator yang menunjukkan minat siswa. Dari yang diungkapkan oleh mahasiswa pendidikan ekonomi angkatan 2016 di STKIP PGRI Lumajang dapat kita pahami bahwa mengerjakan tugas merupakan suatu hal yang harus dikedepankan, mengerjakan tugas juga dapat digambarkan sebagai suatu hal untuk memperoleh keinginan kita harus mengerjakan beberapa tugas agar dapat mencapai atau mendapatkan keinginan tersebut dan juga dalam proses mengerjakan tugas tidak lepas dari sikap 
disiplin sebab disiplin merupakan salah satu sikap dasar untuk berwirausaha.

g. Menaati Peraturan

Orang yang berminat terhadap pelajaran dalam dirinya akan terdapat kecenderungankecenderungan yang kuat untuk mematuhi dan menaati peraturan-peraturan yang ditetapkan karena mengetahui konsekuensinya. Hal ini juga berlaku bagi dunia kewirausahaan, jika memiliki kecenderungan untuk tidak mematuhi dan menaati peraturan maka berdampak pada usaha tersebut. Sehingga menaati peraturan merupakan indikator yang menentukan minat seseorang. Dari yang diungkapkan oleh mahasiswa pendidikan ekonomi angkatan 2016 di STKIP PGRI Lumajang kita dapat mengetahui bahwa menaati peraturan merupakan suatu hal yang penting dan menaati peraturan tidak lepas dari disiplin diri sendiri bahwa peraturan ada tidak untuk dilanggar akan tetapi peraturan ada untuk ditaati agar proses berwirausaha dapat lancer kedepannya.

h. Senang berwirausaha

Dengan adanya rasa senang berwirausaha pada diri seseorang maka akan menimbulkan rasa minat dan penasaran dalam berwirausaha dan perasaan tersebut dapat dijadikan salah satu rasa motivasi untuk berwirausaha. Dari yang diungkapkan oleh mahasiswa pendidikan ekonomi angkatan 2016 di STKIP PGRI Lumajang dapat disimpulkan bahwa senang berwirausaha merupakan salah satu cara untuk mendapatkan profit atau keuntungan dan tidak hanya hal tersebut, senang berwirausaha juga mendapatkan pengalaman dan wawasan baru tentang berwirausaha. Menurut Dharmasetiawandan Rosdianto (2016) "Suatu hal yang mempermudah seseorang melakukan pekerjaan atau tindakan yaitu salah satunya emosional, emosional disini dapat dikaitkan dengan adanya rasa senang pada diri seseorang terhadap tindakan atau pekerjaannya, sehingga dengan adanya rasa senang dalam berwirausaha maka dapat mempermudah pekerjaannya serta dapat dijadikan motivasi dalam berwirausaha.

i. Kesiapan untuk berwirausaha

Dalam dunia wirausaha, kesiapan dalam berwirausaha merupakan sikap yang perlu ada untuk menimbulkan minat berwirausaha. Dengan adanya kesiapan tersebut seseorang dapat siap menghadapi berbagai resiko yang akan dihadapinya. Dari yang diungkapkan oleh mahasiswa pendidikan ekonomi angkatan 2016 di STKIP PGRI Lumajang dapat dijelaskan bahwa kesiapankesiapan dalam berwirausaha dapat berupa kesiapan modal, kesiapan barang dan kesiapan mental merupakan sikap siap untuk tidak takut gagal dalam berwirausaha. Hal tersebut juga merupakan suatu sikap untuk mendorong atau memotivasi mahasiswa dalam memulai usaha atau bisnis. Menurut Novitasyari (2017) "Sikap yang penting dalam berwirausaha yaitu kesiapan untuk berwirausaha itu sendiri, dengan siapnya berwirausaha maka orang tersebut siap menghadapi segala resiko yang akan terjadi di masa yang akan datang.

j. Pertimbangan yang matang untuk berwirausaha

Pertimbangan yang matang untuk berwirausaha adalah seorang wirausahawan harus siap mempertimbangkan perencanaan yang matang untuk berwirausaha sebab dengan mempertimbangkan secara matang dapat mengetahui dampak apa yang akan dihadapi beserta solusinya. Dari yang diungkapkan oleh mahasiswa pendidikan ekonomi angkatan 2016 di STKIP PGRI Lumajang yang intinya sama-sama menyatakan bahwa dalam berwirausaha perlu adanya pertimbangan yang matang, sebab dengan adanya pertimbangan yang matang kita dapat mengurangi resiko yang akan dihadapi, jadi sangat perlu adanya pertimbangan yang matang dalam berwirausaha.

Hal ini sesuai dengan pernyataan Setiawati (2017) "Seseorang yang belum atau sudah masuk di dunia wirausaha harus memiliki pertimbangan yang matang untuk berwirausaha sebab dengan adanya pertimbangan-pertimbangan yang matang, wirausahawan tersebut dapat menjalankan usahanya dengan lancar.

k. Memutuskan untuk berwirausaha 
Di dunia wirausaha, jika seseorang tidak memiliki minat untuk memtuskan berwirausaha maka untuk menjadi wirausaha yang baik akan sulit dicapai. Jadi dengan memiliki niat memutuskan terjun di dunia wirausaha, seseorang memiliki motivasi untuk menjadi seorang wirausahawan yang baik kedepannya. Dari yang diungkapkan oleh mahasiswa pendidikan ekonomi angkatan 2016 di STKIP PGRI Lumajang dapat disimpulkan bahwa memutuskan berwirausaha harus siap menerima segala resiko,serta tahu apa yang dilakukan dan jelas tujuan yang akan dicapainya. Menurut Rahmawati (2017) "Sikap yang penting bagi seseorang yang belum terjun di dunia wirausaha adalah sikap dalam mengambil keputusan untuk berwirausaha, karena dengan memutuskan untuk berwirausaha biasanya seseorang telah mempertimbangkan resiko dan keuntungan yang akan diterima dalam berwirausaha di masa yang akan datang.

1. Tidak ada ketergantungan pada orang lain

Tidak ada ketergantungan pada orang lain adalah melakukan suatu hal sendiri tanpa menggantungkan kepada orang lain atau tindakan seseorang yang dilakukan sendiri tanpa bergantung pada orang lain. Dari yang diungkapkan oleh mahasiswa pendidikan ekonomi angkatan 2016 di STKIP PGRI Lumajang mengenai minat berwirausaha khususnya dalam hal tidak ada ketergantungan pada orang lain merupakan salah satu hal penting pada minat berwirausaha bahwa berwirausaha berawal dari sendiri sebab selalu bergantung pada orang lain merupakan hal yang tidak baik ke depannya. Hal ini sesuai dengan pernyataan Wulandari (2013) "Hal-hal kecil yang berdampak besar dalam dunia usaha yaitu salah satunya memiliki sikap tidak menggantungkan pada orang lain. Dengan adanya sikap tersebut kita dapat melewati masa-masa dimana kita belajar akan sesuatu yang berhubungan dengan wirausaha, sebab berwirausaha dimulai dari diri sendiri dan juga dapat mengetahui batasan kita sebagai wirausahawan.

$\mathrm{m}$. Dapat membantu lingkungan sosial

Dengan berwirausaha diharapkan dapat membantu lingkungan yang ada di sekitar tempat wirausaha tersebut terdorong untuk ikut belajar dan bekerja yang tujuannya dapat mengurangi angka pengangguran di sekitar wilayah usaha tersebut, sebab masih banyak masyarakat yang menganggur dan dengan adanya program atau pelatihan tersebut diharapkan menjadi SDM yang baik untuk wirausaha yang tersedia. Dari yang diungkapkan oleh mahasiswa pendidikan ekonomi angkatan 2016 di STKIP PGRI Lumajang mengenai minat berwirausaha khususnya dalam hal berwirausaha dapat membantu lingkungan sosial di sekitarnya memiliki jawaban yang sama, yaitu sama-sama dapat membantu sekitarnya dengan cara membuka lapangan pekerjaan bagi sekitarnya yang tujuannya mengurangi pengangguran/meningkatkan taraf hidup masyarakat sekitarnya. Menurut Sintya (2019) "Salah satu cara mengurangi pengangguran yaitu membuka usaha di lingkungan sekitarnya. Dengan berdirinya usaha disekitar lingkungan maka dapat membantu menarik tenaga kerja khususnya yang belum memiliki pekerjaan. Jadi dengan kita membuka atau mendirikan usaha di lingkungan sekitar (sosial) maka dapat membantu mengurangi pengangguran dengan cara merekrut orang-orang tersebut.

n. Senang jika menjadi seorang wirausahawan

Senang dan bangga menjadi seorang wirausahawan sebab selain dapat menghasilkan profit atau keuntungan yang banyak juga menjadi seorang wirausahawan dapat bebas dalam bekerja. Dari yang diungkapkan oleh mahasiswa pendidikan ekonomi angkatan 2016 di STKIP PGRI Lumajang mengenai senang jika menjadi seorang wirausahawan dapat dijelaskan bahwa dengan adanya kesenangan dalam berwirausaha akan menumbuhkan minat dan kedepannya usaha yang kita lakukan bisa menjadi lebih baik dengan adanya perasaan senang. Menurut Febrianto (2013) “Dengan adanya rasa senang dan bangga menjadi seorang wirausahawan maka orang tersebut sudah bisa dikatakan memiliki pondasi kecil, artinya wirausahawan tersebut ketika berada diposisi bawah (Merugi), orang tersebut tidak terlalu kecewa atau putus asa sebab orang tersebut memiliki sesuatu yang ada dalam dirinya untuk menyakinkan bahwa pekerjaan yang dimilikinya sudah baik dan dia 
bangga akan hal itu.

o. Ketersediaan untuk bekerja keras dan tekun untuk mencapai kemajuan usaha

Memiliki rasa siap untuk bekerja keras dan tekun demi mencapai kemajuan usahanya.. Dari yang diungkapkan oleh mahasiswa pendidikan ekonomi angkatan 2016 di STKIP PGRI Lumajang dapat dinyatakan bahwa kerja keras dan tekun merupakan salah satu sifat dank unci utama yang diperlukan agar usaha kita bisa sukses dalam memajukan usaha yang dimiliki. Menurut Yudhati dan Efendi (2017) "Salah satu kunci sukses adalah tekun dan bekerja keras. Dengan adanya ketersediaan untuk bekerja keras maka seorang wirausaha sudah memiliki sikap atau langkah yang baik untuk mencapai keinginannya.

p. Ketersedian menanggung berbagai macam resiko

Ketersedian menanggung berbagai macam resiko adalah memiliki rasa siap menghadapi dan menanggung berbagai macam resiko ke depannya. Dengan siap menghadapi resiko yang akan diterimanya maka wirausahawan tersebut dapat mengurangi resiko yang tidak terduga ke depannya, Dari yang diungkapkan oleh mahasiswa pendidikan ekonomi angkatan 2016 di STKIP PGRI Lumajang terkait dengan bagaimana cara mengetahui seseorang siap menanggung berbagai macam resiko dalam berwirausaha yaitu terus berusaha meskipun sudah mengalami kerugian itu merupakan salah satu contoh, sedangkan menurut mahasiswa pendidikan ekonomi angkatan 2016 di STKIP PGRI Lumajang terkait dengan bagaimana cara mengetahui seseorang siap menanggung berbagai macam resiko dalam berwirausaha yaitu dengan rasa senang berwirausaha itu menjadi minat menjadi motivasi untuk minat berwirausaha karena jika kita senang dan melaksanakan usaha tersebut tentunya akan meningkatkan minat. Hal ini sesuai dengan pernyataan Sumual dkk (2018) “ Langkah atau sikap awal untuk memajukan dan mengembangkan usaha yaitu siap menanggung berbagai macam resiko, sebab adanya rasa atau sikap siap mengahadapi resiko maka di masa yang akan datang orang tersebut siap untuk melangkah maju apapun kondisinya.

q. Ketersedian Bersedia menempuh jalur dan cara baru

Memiliki sifat dan sikap menerima cara-cara atau sesuatu yang baru demi kemajuan usahanya. Dari yang diungkapkan oleh mahasiswa pendidikan ekonomi angkatan 2016 di STKIP PGRI Lumajang mengenai ketersedian bersedia menempuh jalur dan cara baru merupakan hal yang dilakukan sebab sebagai wirausaha jika tidak memiliki cara baru maka kita akan mengalami ketertinggalan dengan saingan atau wirausaha lainnya.

r. Ketersedian untuk hidup hemat

Memiliki rasa menerima atau siap hidup hemat demi kelangsungan atau perkembangan usahanya. Dari yang diungkapkan oleh mahasiswa pendidikan ekonomi angkatan 2016 di STKIP PGRI Lumajang jawabannya tidak terlalu jauh beda bahwa hidup hemat dapat membantu usaha yang dijalankan agar dapat meminimalisir kerugian yang diperoleh serta juga dapat mengembangkan dan memajukan usahanya tersebut. Ketersediaan untuk hidup hemat merupakan suatu hal yang harus dimiliki semua orang, khususnya para wirausahawan. Jika kita ditanamkan rasa atau sikap hidup hemat sejak dini, maka hasil dari sikap atau kebiasaan tersebut cukup berdampak bagi kehidupan kita, khususnya dalam masalah ekonomi atau finansial. Ketersediaan untuk hidup hemat dapat mengatasi hal-hal yang tidak terduga dalam hidup kita khususnya bagi para wirausahawan. Ketika para pengusaha atau wirausahawan mengalami kejadian tidak terduga seperti bencana, baik bencana alam maupun bencana yang menimpa usahanya sehingga mengakibatkan kerugian. Hal tersebut dapat ditutupi atau diatasi dengan adanya tabungan atau modal dari hasil hidup hemat. 


\section{Kesimpulan}

Berdasarkan penelitian yang telah peneliti lakukan maka dapat ditarik kesimpulan bahwa Faktor-Faktor yang mempengaruhi Minat Berwirausaha Mahasiswa Pendidikan Ekonomi Angkatan 2016 STKIP PGRI Lumajang Tahun Akademik 2020/2021 antara lain: keinginan, perasaan senang, perhatian, perasaan tertarik, giat belajar, mengerjakan tugas, menaati peraturan, senang berwirausaha, kesiapan untuk berwirausaha, pertimbangan yang matang untuk berwirausaha, memutuskan untuk berwirausaha, tidak ada ketergantungan pada orang lain, dapat membantu lingkungan sosial, senang jika menjadi seorang wirausahawan, ketersediaan untuk bekerja keras dan tekun untuk mencapai kemajuan usaha, bersedia menempuh jalur dan cara baru, ketersedian untuk hidup hemat. Seluruh faktor tersebut sebagai acuan dalam minat berwirausaha, dalam penelitian ini, minat berwirausaha dengan hasil observasi rata-rata minat berwirausaha sebesar $63,6 \%$ memilih pilihan ya dalam pengisian kuisioner dan wawancara terhadap beberapa responden mengenai minat berwirausaha, maka dapat disimpulkan bahwa minat berwirausaha sebesar $63,6 \%$ sedangkan yang kurang minat sebesar $36,4 \%$, hal ini membuktikan bahwa minat berwirausaha dari mahasiswa angkatan 2016 cukup besar.

\section{DAFTAR PUSTAKa}

Anggraeni B, Harnanik. Pengaruh Pengetahuan Kewirausahaan Dan Lingkungan Keluarga Terhadap Minat Berwirausaha Siswa Kelas Xi Smk Islam Nusantara Comal Kabupaten Pemalang. Pengaruh Pengetah Kewirausahaan Dan Lingkung Kel Terhadap Minat Berwirausaha Siswa Kelas Xi Smk Islam Nusant Comal Kabupaten Pemalang. 2015;10(1):42-52.

Budiati Y, Yani TE, Universari N. Minat Mahasiswa menjadi Wirausaha (Studi pada Mahasiswa Fakultas Ekonomi Universitas Semarang). J Din Sosbud. 2012;14(1):89-100.

Febrianto. Analisis Minat Berwirausaha Mahasiswa STIE LAMPUNG TIMUR. J Manaj dan Bisnis. 2013;3(2):150-9.

Mahesa AD, Rahardja E. Analisis Faktor-Faktor Motivasi Yang Mempengaruhi Minat Berwirausaha. DIPONEGORO J Manag. 2012;1(1):1-8.

Manado J, Latif MR, Engka DSM, Sumual JI. Pengaruh Persepsi Tentang Modal Usaha, Lokasi, Dan Jenis Dagangan Terhadap Kesejahteraan Pedagang Di Jalan Roda (Jarod) Manado. J Berk Ilm Efisiensi. 2018;18(5):174-85.

Merdekawaty A. Pengaruh Pendidikan Kewirausahaan Terhadap Minat Berwirausaha Mahasiswa Universitas Samawa Sumbawa Besar. 2018;1(2):112-9.

Misrah. Analisis Minat Berwirausaha Mahasiswa Angkatan 2015-2018 Pendidikan Ekonomi Fakultas Ekonomi Universitas Negeri Makassar. Africa's potential Ecol Intensif Agric. 2013;53(9):168999.

Muhammad Mujtaba Mitra Zuana S. Pengaruh Pengetahuan Kewirausahaan Dan Lingkungan Keluarga Terhadap Minat Berwirausaha Siswa Kelas Xi Smkn 1 Dlanggu Kabupaten Mojokerto. Al-’ Adalah J Syariah dan Huk Islam. 2018;3(2):107-19.

Purnamasari W. Pengaruh Lingkungan Keluarga Dan Minat Berwirausaha Dalam Perspektif Pendidikan Ekonomi. 2018;1-47.

Rosdianto, Dharmasetiawan. ANALISIS MINAT BERWIRAUSAHA MAHASISWA ( Studi Kasus : Mahasiswa Fakultas Ekonomi Universitas Islam Indragiri ). J BAPPEDA. 2016;2(2):71-8.

Sintya NM. Pengaruh Motivasi, Efikasi Diri, Ekspektasi Pendapatan, Lingkungan Keluarga, Dan Pendidikan Kewirausahaan Terhadap Minat Berwirausaha Mahasiswa Jurusan Akuntansi Di Universitas Mahasaraswati Denpasar. J Sains, Akunt dan Manaj. 2019;1(1):337-80.

Umy Yonaevy. Hubungan Antara Dukungan Sosial Dengan Minat Berwirausaha Pada Mahasiswa Fakultas Psikologi Universitas Muhammadiyah Surakarta. 2015;151:10-7.

Verni DM. Faktor-Faktor Yang Mempengaruhi Intensi Berwirausaha Siswa Kelas Xi Smk Mitra Bakti Husada Bekasi. J Pendidik [Internet]. 2018;9(2):57-71. Available from: 
http://marefateadyan.nashriyat.ir/node/150

Wulandari S. Pengaruh Efikasi Diri Terhadap Minat Berwirausaha Pada Siswa KELAS XII DI SMK Negeri 1 Surabaya. 2013;1(1):1-20.

Yudhati ME dan M. Pengaruh Ekspektasi Laba Terhadap Minat Berwirausaha (Studi Pada Mahasiswa Angkatan 2013 STIE MBI Jakarta). J AKP [Internet]. 2017;7(2):1-27. Available from: https://ci.nii.ac.jp/naid/40021243259/

Yuli Budiati, Tri Endang Yani NU. Minat Mahasiswa Iyitnjadi Wirausaha (Studi Pada Mahasiswa Fakuttas Ekonomi Universitas Semarang). J Din Sosbud. 2012;14(1):89-101. 